\title{
Preface: Challenges and new frontiers for organizational politics in modern worksites Eran Vigoda-Gadot and Amos Drory
}

\section{Studies in organizational politics: past, present and future}

Organizational politics has been a fruitful field of academic writing and research for more than three decades. Dozens of papers, book chapters, and other publications as well as numerous conference presentations and symposia have been devoted to what was once considered the hidden dynamics of power and influence in organizations, those that create the politicized worksite. In the past decade, the flow of studies has intensified, reflecting the growing interest in this arena. More than 150 studies have been published in professional academic journals that have explored the meaning of this phenomenon, its antecedents, implications, and significance for managers and employees in various fields and sectors and across cultures.

This book is an attempt to provide a comprehensive understanding of a field that for many years seemed interesting, but almost impossible to study empirically. As with other handbooks, we seek to paint the broad picture. Therefore, we have approached most of the scholars who have written about this phenomenon in recent decades and offered them the opportunity to contribute their unique perspectives. Many have agreed to join our journey and have contributed original papers, pre-published works, or updated versions of previously published papers. In sum, approximately thirty chapters were considered for possible inclusion in this volume, of which 19 were finally selected. These articles were carefully chosen for their quality, their clarity and their ability to provide the reader with an integrative look at workplace politics from various perspectives. The result is 19 chapters of what we see as a thoughtful and lucid analysis written by the leading researchers in the field.

The Handbook of Organizational Politics is therefore designed to offer a broad perspective on the fascinating phenomenon of power, influence and politics in modern worksites. This phenomenon has proven meaningful for individuals, groups and other organizational stakeholders, as it is related to various aspects of organizational outcomes and performances. However, politics in organizations is difficult to study because employees, middle managers and corporate leaders are not eager to reveal the political secrets and dynamics that help them get ahead in the workplace and advance their personal agendas. Organizational politics has many definitions, but all of them relate to the use of personal or aggregate power to influence others and achieve one's goals in the workplace. Throughout the years, scholars have studied not only the positive and negative aspects of politics and its internal structure, but also its antecedents and potential outcomes. The book discusses most, if not all, of these themes, as detailed in the partial list below. The book is intended as a comprehensive collection of original or re-worked studies that together comprise a current picture of our knowledge about this area. This portrait is based on both theoretical ideas and empirical findings from around the globe. 


\section{The art of workplace politics}

Organizational politics has been studied empirically for more than two decades, but its theoretical foundations can be traced back as far as half a century ago. In a previous book (Vigoda, 2003), we stated that organizational politics represents a unique domain of interpersonal relations in the workplace. Its main characteristic is the readiness of people to use power in their efforts to influence others and secure personal or collective interests or, alternatively, avoid negative outcomes within the organization (Bozeman et al., 1996).

In recent decades, organizational politics has become a topic of prime importance in management literature. In the late 1950s, Lasswell claimed that politics is important because it represents the secret of 'who gets what, when, and how' in a social system (Lasswell, 1958). However, until the 1970s, politics in organizations received little or no attention. Only with the recognition that, as in the national arena, organizations also have to deal with conflicts, resource-sharing processes, and power struggles among their members and units has organizational politics begun to attract growing attention. In the late 1970s and early 1980s, some studies established a theoretical framework for the inquiry into the role of politics in the workplace (Bacharach and Lawler, 1980; Mayes and Allen, 1977; Mintzberg, 1983; Pfeffer, 1981).

In the early 1990s, Pfeffer (1992, p. 8) argued that organizations, particularly large ones, are like governments in that they are fundamentally political entities. To understand them one needs to understand organizational politics, just as to understand governments one needs to understand governmental politics. As interest in organizational politics grew, so did the variety of approaches to its study (Vigoda, 2003). For example, some studies have tried to typologize the various influence tactics found in the workplace (for example, Kipnis et al., 1980), while others have used a theory of organizational conflict to explain power struggles and influence tactics (for example, Putnam, 1995). Most of these studies have focused on the nature and expressions of organizational politics and have done so using a negative perspective that equates organizational politics with the dark side of human behavior, such as manipulation, coercive influence, or other subversive and semilegal actions (for example, Ferris and King, 1991; Mintzberg, 1983, 1989). Few have used a balanced approach to determine the effects of organizational politics on employees' attitudes, behavior and performance in the workplace. The relationship between organizational politics and organizational outcomes is important because every member of an organization has power and exercises it in a unique way to benefit himself/herself in his/her work environment. Power, influence and politics have at least some effect on every member of an organization and thus on the entire organizational unit. Therefore, many scholars have argued that the relationship between organizational politics and organizational outcomes is an important one that deserves further inquiry (Bozeman et al., 1996; Ferris and Kacmar, 1992; Kacmar and Carlson, 1994). During the 1990s and on into the twenty-first century, the interest in organizational politics began to focus on people's perceptions about the political maneuvers in their workplaces. This shift in focus was based on the assumption that the reality of politics is best understood through the perceptions of individuals.

Indeed, most of the relatively few studies on organizational politics have concentrated on employees' perceptions of politics (Vigoda, 2003, pp. 7-8). To date, two approaches to organizational politics have dominated the literature. The first focuses on employees' influence tactics at work as the best expression of political behavior. This line of research 
proposes a variety of typologies for influence tactics as well as possible antecedents and consequences of various influence tactics (i.e. Allen et al., 1979; Brass, 1984; Burns, 1961; Cheng, 1983; Erez and Rim, 1982; Izraeli, 1975; Kipnis et al., 1980). The second approach is more recent and focuses on employees' subjective perceptions of organizational politics rather than on political behavior or influence tactics (i.e. Ferris et al., 1994, 1996, 1998; Kacmar and Ferris, 1991; Vigoda, 2000, 2001, 2002; Vigoda-Gadot and Kapun, 2005). As was suggested by Kacmar and Ferris (1991, pp. 193-4) and Kacmar and Carlson (1994, p. 3), perceptions of organizational politics represent the degree to which respondents view their work environment as political in nature, promoting the self-interests of others, and therefore unjust and unfair from the individual's point of view. These studies proposed a scale for the measurement of political perceptions called the 'Perceptions of Organizational Politics Scale' (POPS). Many of the chapters included in this volume have used this scale in their research, making their studies quite comparable with one another. Notwithstanding, one should clearly distinguish between actual political behavior in the workplace and the perceptions of this behavior. Actual political behavior differs conceptually from perceptions of politics. It is, however, related to perceptions, and the nature of both phenomena is posited and tested in this volume, along with some relationships between them.

In an earlier work we indicated that organizational politics is a controversial concept (Vigoda, 2003). While there is no doubt that internal politics is a common phenomenon in every organization, too little is known about the exact nature and boundaries of such machinations even today (Cropanzano et al., 1997; Kipnis et al., 1980; Mayes and Allen, 1977). Clearly, there is a growing need to fill in the missing pieces of this puzzle. This volume is intended as a major step in that direction.

\section{The framework of the book}

The book is presented in five sections that embody the core areas of research in modern studies of organizational politics. These five sections focus on the individual's viewpoint: values issues including ethics, justice and trust; emotions and stress; systems and performance analysis; and professional perspectives on organizational politics. We believe these areas to be representative of many research approaches in this field. In recent years, we have seen a veritable explosion of studies that have introduced a broad range of perspectives, methods and research tools to the study of organizational politics. All of them have contributed to advancing our knowledge in this area. This book, two years in the making, tries to do justice to the wide variety of approaches to the study of organizational politics by selecting representative material created by an influential list of contributors.

\section{Part I: The individual's perspective}

The first part of this volume deals with the micro level and sub-topics of organizational politics that, by nature, relate to individuals and their role in the workplace. It consists of five chapters. The first, by Eran Vigoda-Gadot and Yinnon Dryzin-Amit, deals with the significance of organizational politics for managers in their role as leaders. The authors argue that for many years studies have dealt with the relationship between leadership and organizational performance, but have paid little attention to workplace politics as a mediating factor. This chapter proposes that perceptions of politics among public sector employees are a possible mediator between the supervisor's leadership style and formal and 
informal aspects (organizational citizenship behavior - OCB) of the employees' performance. The chapter develops a theoretical framework that should be tested empirically in future studies. Its main contribution is in taking the theory of organizational politics into different realms and exploring its usefulness beyond what is already known in the literature.

The second chapter, by John P. Meriac and Peter D. Villanova, is intended to study agreeableness and extraversion as moderators of the political influence compatibility-work outcomes relationship. The objectives of this study were threefold: to provide additional support for the notion that political tactics relate differently to work outcomes, to test whether political influence compatibility (PIC) explains incremental variance in the same work outcomes better than perceived political climate, and to explore whether agreeableness or extraversion moderated the PIC-outcomes relationship. Mariac and Villanova used an impressive sample of 479 employees of a large southeastern US merchandising company who completed questionnaires designed to measure their political influence climate perceptions, orientation toward influence tactics and work attitudes. The interesting results indicated that political tactics were related to work outcomes in a variety of ways. Furthermore, while PIC explained incremental variances in work outcomes over and above those explained by political climate, extraversion moderated this relationship only partially. This chapter is unique in using the concept of Person Organization Fit (POF) in relation to organizational politics. Its use raises the issue of people's political fit with the organization and the impact that fit has on their work performance.

The third chapter, by Christopher C. Rosen, Chu-Hsiang Chang and Paul E. Levy, deals with organizational politics and personality. The purpose of this insightful chapter is threefold. First, the authors present a review of the literature that relates personality to perceptions of organizational politics. This review discusses personality as an antecedent to perceptions of politics, as well as the role of personality variables in moderating the relationships between politics and outcomes. Second, they use the perspective of an individual to discuss the multiplicity of effects that personality variables have on the relationship between politics and outcomes. Finally, the authors present an empirical study to illustrate this approach, focusing on the interactive effects of perceptions of politics, self-monitoring and agreeableness. Results supported the proposed three-way interaction and suggested that perceptions of politics have positive effects on organizational citizenship behaviors for employees who report having higher levels of self-monitoring and agreeableness. Finally, the authors speculate on the implications of these findings and discuss them within the context of a process-oriented framework that is used to link organizational politics to work-related attitudes and behaviors.

The fourth chapter in this part, written by Keith James, offers a different look at the individual's perception of politics. Through his middle-level research on the behavior of individuals as part of larger bodies such as work groups, James suggests that fully understanding and managing organizational politics requires considering group-level (collective) politics as well as politics at the individual level. He argues that while most studies of organizational politics consider only the perspective of the individual, the causes, mechanisms and results of collective politics in the workplace are key issues that must be considered as well. James defines politics as the use of means other than formal organizational systems, policies, or procedures to try to control resources, people, or decisions. This definition is rather unusual, but it paves the way for the argument that collective politics can yield both positive outcomes (e.g. flexibility, broad representation) and negative 
ones (e.g. inequitable distributions, polarization of factions). The chapter successfully integrates intergroup and intragroup political processes. Its examination of context influences on the tone and direction of politics in the workplace helps explicate the circumstances that lead to positive rather than negative collective organizational political outcomes. James reviews the limited literature focusing directly on collective organizational politics. He highlights a number of relevant ideas and findings from studies that have examined organizational politics from the point of view of the individual. In addition, he extrapolates some works on collective politics in non-organizational (e.g. national) settings to collective politics in organizations. Finally, James suggests a new, integrative model with which to study the causes, moderators and process of collective politics in organizations.

The final chapter in this part, by Amos Drory and Nurit Zaidman, highlights the concept of impression management in organizations as a political behavior. It suggests that impression management in organizations has been widely recognized among researchers and organizational behavior scholars as behavior performed by the individual attempting to control or manipulates others' attributions and impressions of him or her. In the organizational context impression management is therefore considered a subset of political tactics focusing on influencing others in order to serve the needs of the individual. The chapter by Drory and Zaidman discusses the ways in which individuals use impression management at work to serve their own interests and the factors which determine the choice of impression management tactics. The main thrust of this chapter is to discuss the role of contextual factors in determining how self-impression is manipulated in organizations. The chapter presents both qualitative and quantitative findings to demonstrate the relationship between contextual variables such as organizational norms culture, and sociocultural characteristics and impression management tactics.

\section{Part II: Ethics and fairness}

The second part of the volume looks at values and moral considerations in organizational politics. Three chapters are included in this part. The first chapter, by Chris Provis, offers a fresh definition of organizational politics from a philosophical viewpoint, with an eye to a direct discussion about ethical considerations. Provis proposes addressing some of the normative and ethical issues in organizational politics in the same sorts of ways that political theory has addressed issues that arise in the politics of nation-states. To do so, he suggests that we must eschew definitions of organizational politics that incorporate common negative assumptions. Those assumptions hinder us from a full theoretical understanding of organizational politics, in particular from seeing similarities between organizational politics and other varieties of politics. They also obscure a number of genuine ethical dilemmas and problems. Hence, Provis suggests that we should not evaluate tactics by how well they conform to organizational demands or promote organizational objectives. One may take issue with a definition because the definition itself may play a part in political processes. However, any definition should leave open the possibility of viewing organizational politics as an important activity that is subject to ethical analysis, but can still be important and even praiseworthy. Evaluation of specific cases will often be hindered by the fact that it is hard to discern people's real motives and intentions, but that does not mean that evaluation is impossible or that we should abandon efforts to work out principles that underlie sound ethical evaluations. 
From the vantage point of the philosopher, we advance to that of the psychologist who, in the second chapter, is looking at organizational justice as a mediator between organizational politics, organizational support and organizational commitment. The study by Simon Albrecht extends the research on the relationship between organizational politics, organizational support, organizational trust and organizational commitment. Moreover, the study tests whether or not organizational trust mediates the influence of organizational politics and organizational support on organizational commitment. The sample on which the conclusions are based consisted of 306 full-time employees occupying a diverse number of roles within a large medical facility. Confirmatory factor analysis showed that employees could clearly discriminate between organizational politics, organizational support, organizational trust and organizational commitment. Structural equations modeling showed that, as predicted, organizational politics was inversely related to organizational support and organizational trust. Organizational trust strongly influenced organizational commitment. Contrary to expectations and previous research findings, organizational support did not mediate the relationship between organizational politics and organizational commitment and did not directly influence organizational commitment. Rather, the results showed that organizational trust fully mediated the relationship between organizational support and organizational commitment. However, organizational trust did not mediate the relationship between organizational politics and organizational commitment. Albrecht discusses the results in terms of the important role that politics plays in shaping trust and support, and the important role that organizational trust plays in shaping organizational commitment.

Finally, Constant D. Beugré and Patrick R. Liverpool deal with organizational politics as a determinant of perceptions of fairness in organizations. In this chapter, the authors focus on the possibility that politics and trust are separate phenomena and question the extent to which perceptions of politics influence perceptions of fairness, equity and justice in organizations. While this is an unusual approach to organizational behavior theory, the authors argue that understanding the impact of politics on justice is important. Just as politics is ubiquitous in organizational life, they claim, so are issues of fairness and unfairness. Beugré and Liverpool maintain that the literature of both organizational politics and organizational justice may enrich each other because the two concepts tend to have similar antecedents and produce similar consequences. Moreover, organizational politics and organizational justice are both perceptual phenomena. Given that people are more likely to act based on their perception of reality rather than on reality itself (Lewin, 1936), it is important to understand how perceptions of politics influence notions of fairness. The chapter is divided into four sections. In the first, the authors define the concepts of politics and justice. This is followed by an explanation of the relationship between perceptions of politics and perceptions of justice. In the third, they develop and explain a theoretical model of the relationship between the two concepts. The fundamental premise of this model is that perceptions of organizational politics negatively affect perceptions of justice. Finally, the authors discuss the model's implications for practice and research.

\section{Part III: Emotions and stress}

The third part moves beyond the individual and ethical levels to explore the mental and physical consequences of highly politicized modern worksites. It concentrates on the emotions and stress that are involved in the political process in organizations. The three 
chapters included in this part provide cutting-edge theories and empirical findings about the covert aspects of power and politics and their consequences for the mental health of the individual and his/her surroundings. The first chapter, by Russell Cropanzano and Andrew Li, elaborates on the meaning and implications of the relationship between organizational politics and stress. In this chapter, the authors systematically and thoroughly review the research literature relating organizational politics to workplace stress. They open the discussion by considering three different definitions of stress. First, stress is depicted as an environmental event that may engender negative reactions from employees. Second, stress is defined as a cognitive appraisal that one's resources are overwhelmed by environmental demands. Third, stress is considered as a response to adverse working conditions. A review of each of these definitions provides insights into the dynamics of organizational politics, but each one also raises unanswered questions. After considering stress, Cropanzano and Li turn their attention to organizational politics. They begin by discussing the treatment of politics as a neutral event, rather than as a negative occurrence. They then turn their attention to the distinction between actual political behavior and perceived organizational politics. As they demonstrate, each of these conceptualizations of organizational politics has different implications for the etiology of stress. The chapter concludes with a thought-provoking, integrative model that underscores conceptual needs and acts as an impetus for future research.

The second chapter, by Yongmei Liu, Gerald R. Ferris, Darren C. Treadway, Melita L. Prati, Pamela L. Perrewé and Wayne A. Hochwarter, explores affective and cognitive reactions to politics as a stressor and proposes a discussion of the 'emotion of politics and the politics of emotions'. The authors suggest that despite the increased interest in organizational politics in recent years, only minimal research has examined the role of emotion in organizational politics processes. In this chapter, the authors propose a conceptualized linking of perceptions of organizational politics with emotion, which is focused at both the individual and dyadic levels of analysis. They argue that emotion and emotional behaviors serve as intermediate linkages in the relationships between perceptions of organizational politics and both attitudinal and behavioral outcomes. Specifically, the chapter draws from research on organizational politics, affective events theory, and socialpsychological studies of emotion in an effort to advance an emotions-based approach to organizational politics. The authors convincingly demonstrate that there is emotion in organizational politics and organizational politics in emotion, and that the intersection of the two has to be recognized in order to obtain a more complete understanding of both.

The third chapter, by Robyn L. Brouer, Gerald R. Ferris, Wayne A. Hochwarter, Mary Dana Laird and David C. Gilmore, expands the study of stress-related reactions to perceptions of organizational politics. Following Vigoda (2002), this chapter argues that perceptions of politics play the role of a workplace stressor, which produces associated reactions. In keeping with earlier studies, the authors suggest that this relationship holds only for those individuals who have weak political skills. For those with stronger political skills, perceptions of politics should be associated with less negative attitudes and reactions. The chapter is the outcome of a three-tiered investigation into political skill as a moderator of the relationship between perceptions of politics and strain, where strain was defined as symptoms of depression in employees. The convergence of results across the three studies demonstrated that, for those with strong political skills, increases in perceptions of politics were associated with decreases in symptoms of depression. The opposite 
was true for those who were politically less savvy. The authors discuss these results clearly and suggest their thoughts on the implications of the study as well as directions for future research in this area.

\section{Part IV: Systems and performance}

The fourth part of the book is devoted to a macro view of organizational politics and deals with system and performance analysis using issues such as strategy, change and decision making. Five chapters are included in this part, the first of which is an intriguing chapter by Jane Gunn and Stephen Chen devoted to the question of how organizational politics influences strategic decision making. This chapter highlights strategic management from a political perspective. The authors suggest that early strategic management literature assumed strategy making as a rational, logical process. However, they continue, the impact of organizational politics on strategy processes has received little attention. Although many of the rational assumptions have been challenged in academic literature, they continue to influence practice, and research linking strategic management and organizational politics remains limited. Focusing on organizational politics at the micro or intra-organizational level, this chapter critically reviews the literature on strategic management and organizational politics in order to investigate strategic management as a political activity. Gunn and Chen provide a micro-political perspective on strategic management and identify areas for future research. Their unconventional explorations of and explanations for politics at the strategic system level of analysis lay the groundwork for continued studies in this field.

The following chapter, by Simon Albrecht, discusses affective reactions to organizational politics, cognitive assessments and their influence on organizational commitment, and cynical attitudes toward change. This chapter is in keeping with the previous chapter in this part, as it deals with attitudes towards systematic change and performance in organizations. Albrecht begins by suggesting that although there is substantial empirical evidence supporting the important role that politics plays in organizational contexts, there is limited empirical evidence that focuses on the distinction between how employees feel about organizational politics and what they think about organizational politics. Exploratory and confirmatory factor analysis of survey data $(N=365)$ collected from full-time workers employed in a broad range of organizations showed that respondents could reliably discriminate between what they think about organizational politics (as measured by POPS), and how they feel about organizational politics. Newly developed measures of affective reactions to organizational politics identified two distinct dimensions - one positive and one negative. Regression analyses showed that the affective dimensions of organizational politics predicted variance in affective commitment and attitudes to change beyond that accounted for by what employees think about politics (as measured by the POPS) and by how they perceive organizational support (as measured by the Survey of Perceived Organizational Support - SPOS). More specifically, positive feelings about organizational politics explained variance in organizational commitment beyond that explained by perceptions of organizational politics and organizational support. Negative feelings about organizational politics explained variance in cynicism toward change beyond that explained by perceptions of organizational politics and organizational support. Supplementary analysis showed that negative affective reactions to politics partially mediated the relationship between cognitive perceptions of politics 
(POPS) and cynicism toward change. Finally, Albrecht provides implications for further research on organizational politics.

The third chapter, by Jonathon R.B. Halbesleben and Anthony R. Wheeler, explores the relationship between perceptions of politics, social support, withdrawal and performance at the organizational level. In this chapter, the authors view withdrawal and performance as significant factors with considerable effects on system-level outcomes. They hypothesize that social support moderates the relationship between perceptions of politics (POP) and employee withdrawal behaviors (the depersonalization component of burnout), which in turn mediates the relationship between POP and employee performance. Study 1 was based on a sample of 83 firefighters and found support for the hypothesized relationship between the variables. Study 2 was more ambitious and sampled 521 full-time employees from two geographic regions in the USA. It in essence replicated the findings of Study 1. Both studies supported the proposed model, indicating a process underlying the relationship between POP and performance that is linked to the conservation of resources. Helbesleben and Wheeler conclude that the inclusion of social support and withdrawal behaviors in the POP-performance relationship extends the literature on politics. They also offer practical recommendations to assist human resource managers in handling the system consequences of politics in organizations.

The fourth chapter, by Wayne A. Hochwarter, Robert W. Kolodinsky, Lawrence A. Witt, Angela T. Hall, Gerald R. Ferris and Michele K. Kacmar, offers competing views about the role that understanding plays in the relationship between perceptions of politics and job performance. The authors argue that to date, research examining the role of understanding as a moderator of the relationship between organizational politics perceptions and work outcomes has paid disproportionate attention to attitudinal or affective worker reactions, largely ignoring behavioral outcomes, such as job performance. To fill this void, the authors tested two competing hypotheses. The first posited that better understanding serves as an antidote and reduces the negative effects of politics on job performance. The second took a different tack, arguing that better understanding distracts employees from their work and hinders their performance. Hierarchical, moderated, multiple regression analyses results from three studies convincingly support the 'distraction' hypothesis. The chapter concludes with a discussion about the contributions of these results, the study's strengths and limitations, practical implications and directions for future research, all of which underscore the potential that testing moderators hold for the study of organizational politics.

The final chapter in this part, by David Butcher and Martin Clarke, elaborates on the relationship between organizational politics and organizational democracy and questions whether the two can exist symbiotically or are by nature at war with one another. In the last 20 years, substantial changes in the structure of the economy have forced businesses to rethink the way they approach the distribution of organizational influence. However, despite these developments there is still increasing evidence that employees do not always see themselves as beneficiaries of such change. Surveys and reports regularly highlight unacceptable levels of employee cynicism, disillusionment and alienation. Attempts to install democratic principles in organizations do not always work. Much has changed, but much has also remained the same. Some piece of the jigsaw puzzle is missing. It is a piece that has long been viewed as integral to governmental democracy, but strangely enough, has been seen as illegitimate in organizational democracy - it is 
politics. The chapter explores this increasing tension between democratized organization forms and the realities of bureaucracies. In this context Clark and Butcher argue that organizational politics is not only an important and necessary managerial discipline, but that models of political behavior are also central to the development of real organizational democracy. The inherent compatibility of organizational politics and democracy is considered. The authors draw on recent research to delineate how the adoption of constructive political behavior derived from a political institutional leadership setting offers a robust model for those the leadership of more democratic organizational forms. They also offer advice on how to work with a constructive political 'mindset' and consider how the progress toward redistributing organizational influence may be accelerated through individual action.

\section{Part V: The professional's perspective}

In the final part of the book we decided to take a more practical look at organizational politics and consider issues related to human resource management and counseling that frequently arise when power and influence are involved in the daily life of managers and employees. We found four articles that addressed these topics very effectively. First, a stimulating chapter by one of the major contributors to organizational development theory and practice, Robert T. Golembiewski, focuses on consulting. He notes that the literature on consulting for and reporting to hierarchical superiors does not address power phenomena, even though there is strong evidence that one ignores such issues at his/her own peril. Golembiewski finds no adequate explanation for the failure to deal with this issue. He suggests that the emphasis on legitimacy may be to blame, especially because this view is so attractive to formal elites in all collective systems. He further suggests that perhaps 'power' or 'politics' in organizations is considered unworthy of attention, with connotations of being 'dirty' or underhand. Golembiewski characterizes power as a necessity of collective life, whose manifestations may be good, bad, or somewhere in between. His chapter goes a long way to remedying this tendency to define power topics as off limits in most organizational theory and practice, as well as in consulting. The chapter also sketches two related practical methods of ameliorating the traditional neglect of this topic. It asks whether 'power' is viewed as derived from legitimate or formal authority or from skills, personality, or other bases. The primary focus of the chapter is on public organizations, but it has general applicability to public sector and NGO contexts as well.

In keeping with Golembiewski's arguments, the chapter by Astrid I. Boogers-van Griethuijsen, Ben J.M. Emans, Janka I. Stoker and Arndt M. Sorge deals with sources of consultants' personal power. Twelve foundations for the power position of consultants are suggested and are based on the assumption that a management consultant is often hired in order to promote organizational change. Therefore, the consultant should possess the qualities deemed necessary to that end. One of those qualities is power vis-à-vis involved organizational members. In this study, the authors contribute to the knowledge of organizational politics by developing a model that explains the sources of power of management consultants. Based on interviews with management consultants, they enumerate expert power, personal power, reputation of the consultancy firm, professional status symbols, indirect formal power, network power, means of exchange, reward power, coercive power, power based on persuasive skills, power based on communicative skills, and power based on analytic skills as relevant power bases for consultants. 
Finally, Ronnie Kurchner-Hawkins and Rima Miller present their experience-based view about the need to build positive strategies of organizational politics in turbulent times. They start with the well-accepted assertion that politics is an organizational reality and develop a chapter that explores how individuals can construct positive strategies for managing organizational politics. The authors view organizational politics neutrally as the exercise of power and influence that primarily occurs outside of formal organizational processes and procedures. A mindset shift continuum is presented describing the attitude and behavior changes that support positive political action. The authors' model of organizational politics provides a context for understanding and constructing positive political strategies. The model identifies eight factors that impact organizational politics. Four behavioral factors - influence, communication/information, relationships/alliances, and networks - serve as 'levers' that can be activated when constructing political strategies. Four additional mediating factors - history, culture, 'past plays' and ethics - provide a context for determining political action. The chapter concludes with a discussion of the implications of implementing positive political strategies for individuals and organizations and emphasizes a practical approach for the management of politics in modern worksites.

\section{Target readers}

This book is intended as a collection of up-to-date, original studies on organizational politics conducted around the world at various levels of analysis and from manifold disciplinary perspectives. It encompasses theoretical, empirical and practical approaches contributed by the leading scholars in the field. Hence it offers serious, analytical material for scholars, students and practitioners alike. Such a collection should be of greatest interest to scholars in various fields of the behavioral and social sciences such as organizational behavior, management and business, occupational psychology, sociology and political science. The book's focus on the internal politics of organizations makes it a useful tool for academics and managers from the public and private sectors looking for better explanations of internal processes in businesses, as well as in large federal or state organizations. However, the mid-level and macro-level analysis of some of the chapters can be used for policy studies and strategic management as well.

While most of the book's readers will probably be academics, the chapters included provide a wealth of information that may prove useful for other audiences. For example, the second section may be of interest to scholars in the humanistic disciplines, and the fifth part of the book is oriented towards practitioners. Many of the empirical data provided throughout the other chapters should help scholars and graduate students in the social sciences seeking a better understanding of intra-organizational dynamics, the development of conflicts in organizations, and the nature of power influence and authority in various worksites. Finally, the book, with its strong academic and empirical orientation, delineates some important current developments in an area that is both covert and hard to study, but which holds great potential and promise for the future understanding of human political behavior in modern worksites and its implications for personal, group and system-level performance.

\section{References}

Allen, R.W., Medison, D.L., Porter, L.W., Renwick, P.A. and Mayes, B.T. (1979). Organizational politics: Tactics and characteristics of political actors. California Management Review, 22, 77-83. 
Bacharach, S.B. and Lawler, E.J. (1980). Power and politics in organizations. San Francisco: Jossey-Bass.

Bozeman, D.P., Perrewe, P.L., Kacmar, K.M., Hochwarter, W.A. and Brymer, R.A. (1996). An examination of reactions to perceptions of organizational politics. Paper presented at the Southern Management Association Meeting, New Orleans, LA.

Brass, D.J. (1984). Being in the right place: A structural analysis of individual influence in an organization. Administrative Science Quarterly, 29, 518-39.

Burns, T. (1961). Micropolitics: Mechanisms of institutional change. Administrative Science Quarterly, 6, 257-81.

Cheng, J.L. (1983). Organizational context and upward influence: An experimental study of the use of power tactics. Group and Organizational Studies, 8, 337-55.

Cropanzano, R., Howes, J.C., Grandey, A.A. and Toth, P. (1997). The relationship of organizational politics and support to work behaviors, attitudes, and stress. Journal of Organizational Behavior, 18, 159-80.

Erez, M. and Rim, Y. (1982). The relationship between goals, influence tactics and personal and organizational variables. Human Relations, 35, 877-8.

Ferris, G.R. and Kacmar, K.M. (1992). Perceptions of organizational politics. Journal of Management, 18, 93-116.

Ferris, G.R. and King, T.R. (1991). Politics in human resources decisions: A walk on the dark side. Organizational Dynamics, 20, 59-71.

Ferris, G.R., Fedor, D.B. and King, T.R. (1994). A political conceptualization of managerial behavior. Human Resource Management Review, 4, 1-34.

Ferris, G.R., Frink, D.D., Bhawuk, D.P.S. and Zhou, J. (1996). Reactions of diverse groups to politics in the workplace. Journal of Management, 22, 23-44.

Ferris, G.R., Harrell-Cook, G. and Dulebohn, J.H. (1998). Organizational Politics: The nature of the relationship between politics perceptions and political behavior. In S.B. Bacharach and E.J. Lawler (eds), Research in the sociology of organizations, Greenwich, CT: JAI Press.

Izraeli, D.N. (1975). The middle manager and the tactics of power expansion: A case study. Sloan Management Review, 16, 57-70.

Kacmar, K.M. and Carlson, D.S. (1994). Further validation of the Perceptions of Politics Scale (POPS): A multiple sample investigation. Paper presented at Academy of Management Meeting, Dallas, Texas.

Kacmar, K.M. and Ferris, G.R. (1991). Perceptions of Organizational Politics Scale (POPS): Development and construct validation. Educational and Psychological Measurement, 51, 193-205.

Kipnis, D., Schmidt, S.M. and Wilkinson, I. (1980). Intraorganizational influence tactics: exploration in getting one's way. Journal of Applied Psychology, 65, 440-52.

Lasswell, H.D. (1958). Politics: who gets what, when, how. Cleveland, OH: World Publishing.

Lewin, K. (1936). Principles of topological psychology. New York: McGraw-Hill.

Mayes, B.T. and Allen, R.W. (1977). Toward a definition of organizational politics. Academy of Management Review, 2, 672-8.

Mintzberg, H. (1983). Power in and around organizations. Englewood Cliffs, NJ: Prentice-Hall.

Mintzberg, H. (1989). Mintzberg on management. New York: Free Press.

Pfeffer, J. (1981). Power in organizations. Marshfield, MA: Pitman Publishing.

Pfeffer, J. (1992). Management with power. Boston: Harvard Business School Press.

Putnam, L.L. (1995). Formal negotiations: The productive side of organizational conflict. In A.M. Nicotera (ed.), Conflict and organizations (pp. 183-200). New York: State University of New York.

Vigoda, E. (2000). The relationship between organizational politics, job attitudes, and work outcomes: Exploration and implications for the public sector. Journal of Vocational Behavior, 57, 326-47.

Vigoda, E. (2001). Reactions to organizational politics: A cross-cultural examination in Israel and Britain. Human Relations, 54, 1483-518.

Vigoda, E. (2002). Stress-related aftermaths to workplace politics: An empirical assessment of the relationship among organizational politics, job stress, burnout, and aggressive behavior. Journal of Organizational Behavior, 23, 571-91.

Vigoda, E. (2003). Developments in organizational politics: How political dynamics affect employee performance in modern work sites. Cheltenham, UK and Northampton, MA: Edward Elgar.

Vigoda-Gadot, E. and Kapoon, D. (2005). Perceptions of politics and performance in public and private organizations: A test of one model across two sectors. Policy and Politics, 33 (2), 251-76. 